\title{
Synthesis and Characterization of Poly(amide-imide)s Based on 1,7-Bis(4-aminophenoxy)naphthalene and Various Bis(trimellitimide)s
}

\author{
Chin-Ping Yang, ${ }^{\dagger}$ Ruei-Shin Chen, and Hung-De Chen \\ Department of Chemical Engineering, Tatung Institute of Technology, \\ 40 Chungshan North Rd., Sec. 3, Taipei 10451, Taiwan, Republic of China
}

(Received May 19, 1999)

\begin{abstract}
Novel poly(amide-imide)s III containing a 1,7-bis(phenoxy)naphthalene unit were synthesized by 1,7-bis(4-aminophenoxy)naphthalene (1,7-BAPON) and various bis(trimellitimide)s in $N$-methyl-2-pyrrolidone (NMP) using triphenyl phosphite and pyridine as condensing agents through direct polycondensation. The polymers were obtained in quantitative yield with inherent viscosities of $0.48-0.91 \mathrm{dL} \mathrm{g}^{-1}$. Most of the polymers were soluble in aprotic dipolar solvents such as $\mathrm{N}, \mathrm{N}$-dimethylacetamide (DMAc) and NMP, and could be solution cast into transparent, flexible, and tough films. The films had yield strength of $85-97 \mathrm{MPa}$, tensile strength of 73-103 MPa, elongation at break of $9-69 \%$, and initial modulus of $1.89-2.35 \mathrm{GPa}$. Wide-angle X-ray diffraction revealed that most polymers III are amorphous. The glass transition temperatures of some polymers could be determined by differential scanning calorimetry (DSC) traces, recorded at $213-250^{\circ} \mathrm{C}$. The $10 \%$ weight loss temperatures of the polymers were in the range of $514-579^{\circ} \mathrm{C}$ in nitrogen, and char yields of polymers at $800^{\circ} \mathrm{C}$ in nitrogen were higher than $50 \%$.

KEY WORDS 1,7-Bis(phenoxy)naphthalene / Poly(amide-imide)/
\end{abstract}

Wholly aromatic poly(amide-imide)s (PAIs) are an important class of material having excellent resistance to high temperatures and favorable balance of other physical and chemical properties. ${ }^{1-3}$ Our laboratory has developed a convenient method for PAIs synthesis. The method involves trimellitic anhydride (TMA) and diamine to prepare an imide ring-preformed dicarboxylic acid, which is then reacted with another aromatic diamine to prepare PAIs by direct polycondensation. ${ }^{4,5}$ This technique has been reported by Yamazaki et al. for the synthesis of polyamides. ${ }^{6}$ PAIs have the advantages of both polyamides and polyimides, such as excellent mechanical and thermal properties as well as solvent resistance.

The introduction of a naphthalene ring into the polymer backbone is expected to decrease the linearity of the polymer chain while maintaining comparable thermal stability in comparison with the benzene ring. Aromatic ether linkages inserted into polymer main chains can lower the energy of internal rotation significantly. ${ }^{7,8}$ In general, such a structural modification leads to significant improvement in solubility. Hence, the combination of aryl ether and naphthalene units into the polymer chain may be proposed as a new means for improving the solubility of polymers without extreme loss of thermal stability. ${ }^{9-14}$

In our previous articles, some PAIs ${ }^{15}$ containing 1,7-bis(phenoxy)naphthalene units and some isomeric PAIs ${ }^{16-20}$ containing bis(phenoxy)naphthalene units were soluble in polar organic solvents and maintained thermal stability. As continuation of that study, this article describes the synthesis of a series of novel PAIs III from 1,7-bis(4-aminophenoxy)naphthalene and various bis(trimellitimide)s, which were prepared from the condensation of TMA and various aromatic diamines. Solubility, tensile properties, crystallinity, and thermal

\footnotetext{
† To whom correspondence should be addressed.
}

behavior of the obtained polymers were investigated and compared with those of the corresponding poly(amideimide)s III'.

\section{EXPERIMENTAL}

\section{Materials}

1,7-Naphthalene diol (1,7-NDO; from TCI), $p$ phenylenediamine (Ia; from Wako) and $m$-phenylenediamine (Ib; from TCI) were vacuum-distilled before use. All other diamines such as 2,4-diaminotoluene (Ic; from TCI), 4,4'-methylenedianiline (Id; from TCI), 4,4'oxydianiline (Ie; from TCI), 3,4'-oxydianiline (If; from Teijin Ltd., Tokyo), 4,4'-thiodianiline (Ig; from TCI), 4,4'-(1,4-phenylenedioxy)dianiline (Ih; from TCI), 2,2bis[4-(4-aminophenoxy)phenyl]hexafluoropropane (Ij; from TCI) were used as received. The diamines 4,4'[isopropylidenebis(1,4-phenyleneoxy)]dianiline (Ii) and 4,4'-[sulfonyl-bis(1,4-phenyleneoxy)]dianiline (Ik) were obtained from Chriskev Corp. and used without further purification. According to a reported method, ${ }^{21}$ 1,1bis[4-(4-aminophenoxy)phenyl]-1-phenylethane (II) is prepared by nucleophilic substitution reactions of the corresponding aromatic diols and $p$-chloronitrobenzene followed by catalytic hydrazine reduction. TMA (from Wako) and triphenyl phosphite (TPP; from TCI) were used as received. Commercially available anhydrous calcium chloride $\left(\mathrm{CaCl}_{2}\right)$ was dried under reduced pressure at $150^{\circ} \mathrm{C}$ for $6 \mathrm{~h}$ prior to use. $N$-Methyl-2pyrrolidone (NMP; from Fluka), $N, N$-dimethylacetamide (DMAc; from Fluka), $N, N$-dimethylformamide (DMF; from Fluka), and pyridine (Py; from Wako) were purified by distillation under reduced pressure over calcium hydride and stored over $4 \AA$ molecular sieves.

\section{Synthesis of 1,7-Bis(4-aminophenoxy)naphthalene (1,7- $B A P O N)$}

The dinitro compound 1,7-BNPON was synthesized 
by reaction of 1,7-NDO and p-fluoronitrobenzene (or $p$-chloronitrobenzene) in the presence of $\mathrm{K}_{2} \mathrm{CO}_{3}$ in DMAc at $160^{\circ} \mathrm{C}$ for $8 \mathrm{~h}$. After purification, 1,7-BNPON was reduced with hydrazine and $\mathrm{Pd} / \mathrm{C}$ in ethanol to the diamine 1,7-BAPON $(70 \%$ yield $) ; \mathrm{mp} 133-135^{\circ} \mathrm{C}^{22}$

IR (KBr): $3450,3364 \mathrm{~cm}^{-1}(\mathrm{~N}-\mathrm{H}) .{ }^{1} \mathrm{H}$ NMR (dimethyl sulfoxide $\left.(\mathrm{DMSO})-d_{6}\right): \delta(\mathrm{ppm})=7.90-7.21(\mathrm{~m}, 6 \mathrm{H}$, naphthalene protons), $6.85\left(\mathrm{~d}, 2 \mathrm{H}, \mathrm{H}_{\mathrm{b}}\right), 6.77\left(\mathrm{~d}, 2 \mathrm{H}, \mathrm{H}_{\mathrm{c}}\right)$, $6.62\left(\mathrm{dd}, 4 \mathrm{H}, \mathrm{H}_{\mathrm{a}}+\mathrm{H}_{\mathrm{d}}\right), 4.98\left(\mathrm{~d}, 4 \mathrm{H}\right.$, amino group). ${ }^{13} \mathrm{C}$ NMR (DMSO- $\left.d_{6}\right): \delta(\mathrm{ppm})=157.15,154.04,145.70$, $145.53,145.26,130.30,129.77,126.11,123.97,121.17$, $120.88,119.33,115.01,114.92,110.18,104.39$.

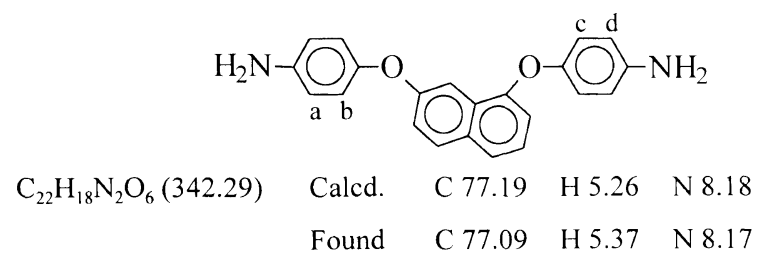

\section{Synthesis of Diimide-Dicarboxylic Acid}

Diimide-dicarboxylic acids were synthesized from TMA with various aromatic diamines as follows: a mixture of TMA $(120 \mathrm{mmol}, 23.04 \mathrm{~g})$ and $m$-phenylenediamine (Ib) $(60 \mathrm{mmol}, 6.48 \mathrm{~g})$ was dissolved in $100 \mathrm{~mL}$ dry DMF and stirred till the solution was clear. Toluene $(30 \mathrm{~mL})$ was added and the mixture was heated to $140^{\circ} \mathrm{C}$ until water (about $2.2 \mathrm{~mL}$ ) was distilled off azeotropically. Heating was continued to distill off the residual toluene. After cooling, the precipitate of IIb was isolated by filtration and recrystallization from DMF, and was dried to give $26.84 \mathrm{~g}$ of IIb $\left(98 \%\right.$ yield); $\mathrm{mp} 412-413^{\circ} \mathrm{C}$ (by DSC). ${ }^{23}$

IR (KBr): 3436 (acid-OH), 1700 (acid $\mathrm{C}=\mathrm{O}), 1777$, $1729 \mathrm{~cm}^{-1}$ (imide ring $\mathrm{C}=\mathrm{O}$ ).

$$
\mathrm{C}_{24} \mathrm{H}_{12} \mathrm{~N}_{2} \mathrm{O}_{8} \text { (456.37) Calcd C } 63.16 \mathrm{H} 2.65 \mathrm{~N} 6.14
$$

Found C 62.65 H 2.93 N 6.23

Other diimide-dicarboxylic acids were synthesized similarly.

\section{Polymerization}

A typical example of polycondensation is as follows. A mixture of $0.426 \mathrm{~g}(1.25 \mathrm{mmol})$ of $1,7-\mathrm{BAPON}, 0.685 \mathrm{~g}$ $(1.25 \mathrm{mmol})$ of diimide-diacid IIe, $0.56 \mathrm{~g}$ of calcium chloride, $1.6 \mathrm{~mL}$ of pyridine, $0.8 \mathrm{~mL}$ of triphenyl phosphite and $6.0 \mathrm{~mL}$ of NMP was heated while being stirred at $100^{\circ} \mathrm{C}$ for $3 \mathrm{~h}$. The viscosity of reaction solution increased after $1 \mathrm{~h}$, and an additional volume of $4 \mathrm{~mL}$ of NMP was added to the reaction mixture. At the end of the reaction, the obtained polymer solution was trickled into $400 \mathrm{~mL}$ stirred methanol. The stringy polymer was washed thoroughly with hot water and methanol, collected by filtration and dried at $100^{\circ} \mathrm{C}$ under reduced pressure. The yield was quantitative. The inherent viscosity of the polymer IIIe was $0.91 \mathrm{dL} \mathrm{g}^{-1}$, measured with a polymer concentration of $0.5 \mathrm{~g} \mathrm{dL}^{-1}$ in DMAc at $30^{\circ} \mathrm{C}$.

Other PAIs were synthesized in a similar manner.

\section{Measurements}

IR spectra were recorded on a JASCO FT-IR-7000 Fourier-transform Infrared Spectrometer. Elemental analyses were carried out in a Perkin-Elmer Model 2400
$\mathrm{C}, \mathrm{H}, \mathrm{N}$ analyzer. The inherent viscosities of all polymers were determined at a concentration of $0.5 \mathrm{~g} \mathrm{dL}^{-1}$ in DMAc at $30^{\circ} \mathrm{C}$ using a Cannon-Fenske viscometer. Solubility was determined at $1 \%(\mathrm{w} / \mathrm{w})$ concentration. Differential scanning calorimetry (DSC) was performed on a Sinku Riko DSC-7000 differential scanning calorimeter coupled to a Sinku Riko TA-7000 thermal analysis controller in flowing nitrogen $\left(30 \mathrm{~cm}^{3} \mathrm{~min}^{-1}\right)$ at a heating rate of $20^{\circ} \mathrm{C} \mathrm{min}^{-1}$. Thermogravimetry (TG) was done on a Rigaku Thermoflex TG 8110 coupled to a Rigaku TAS-100. Measurements were performed with $10 \pm 2 \mathrm{mg}$ of samples heated in flowing nitrogen $\left(50 \mathrm{~cm}^{3}\right.$ $\min ^{-1}$ ) at a heating rate of $20^{\circ} \mathrm{C} \mathrm{min}^{-1}$. Wide-angle $\mathrm{X}$-ray diffraction patterns were obtained on a Rigaku Geiger Flex D-Max IIIa, using Ni-filtered $\mathrm{Cu}-K_{\alpha}$ radiation $(40 \mathrm{kV}, 15 \mathrm{~mA})$ with powder or film specimens of about $0.1 \mathrm{~mm}$ in thickness. Instron Universal Tester Model 1130 with a load cell of $5 \mathrm{~kg}$ was used to study the stress-strain behavior of the sample. A gauge of $2 \mathrm{~cm}$ and strain rate of $5 \mathrm{~cm} \mathrm{~min}^{-1}$ were used for this study. Measurements were performed at room temperature with film specimens $(0.5 \mathrm{~cm}$ wide, $6 \mathrm{~cm}$ long, and about $0.05 \mathrm{~mm}$ thick), and the average of at least five individual determinations was reported.

\section{RESULTS AND DISCUSSION}

\section{Monomer Synthesis}

1,7 -BAPON had varying yields $(30-70 \%$ from $1,7-$ NDO), affected by $p$-chloronitrobenzene or $p$-fluoronitrobenzene, as shown in Scheme 1. In general, $p$ chloronitrobenzene was reacted at $160^{\circ} \mathrm{C}$ and had low yield, but $p$-fluoronitrobenzene was reacted at $120^{\circ} \mathrm{C}$ and had high yield up to $56 \%$. Due to higher electronegativity of fluorine atom, $p$-fluoronitrobenzene had higher reactivity than $p$-chloronitrobenzene. Various bis(trimellitimide)s were synthesized from the condensation of diamines with TMA. The crude diimide-diacids were purified by recrystallization from DMF for producing high molecular weight. The structures of monomers were confirmed by elemental analysis and infrared, ${ }^{1} \mathrm{H}$ NMR, and ${ }^{13} \mathrm{C}$ NMR spectroscopy. The ${ }^{13} \mathrm{C}$ NMR spectra of 1,7-BAPON exhibit 16 resonance peaks, respectively, possibly due to the chemical shift of the phenylene protons of the two phenoxy units are slightly different.

\section{Polymer Synthesis}

By different procedures, PAIs, synthesized from two diamines and TMA, had amide-amide and imide-imide sequences, as shown in Scheme 2. In the III' series of our previous article, 1,7-BAPON was located between two imide groups in the PAI chain. In this study, the III series containing 1,7-BAPON between two amide groups was synthesized. The results of the preparation of PAIs III are summarized in Table I. Reaction solutions were homogeneously transparent in high monomers concentration, and an additional volume of NMP was added to the reaction mixture when viscosity of solution increased. Most of the polymers produced stringy precipitates. The inherent viscosities of the III series solutions transparent during polymerization were $0.48-0.91 \mathrm{dL} \mathrm{g}^{-1}$. The unsatisfactory results may be attributed to the nature of 1,7-BAPON. Especially, in 


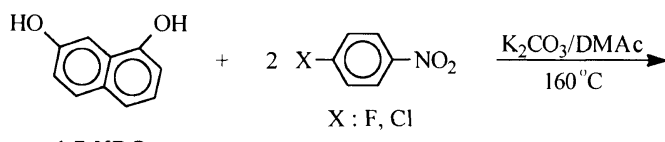

1,7-NDO<smiles>O=[N+]([O-])c1ccc(Oc2cccc3cccc(Oc4ccc([N+](=O)[O-])cc4)c23)cc1</smiles>

1,7-BNPON

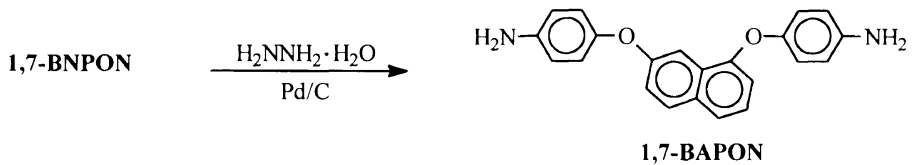

Scheme 1. Preparation of diamine 1,7-BAPON.
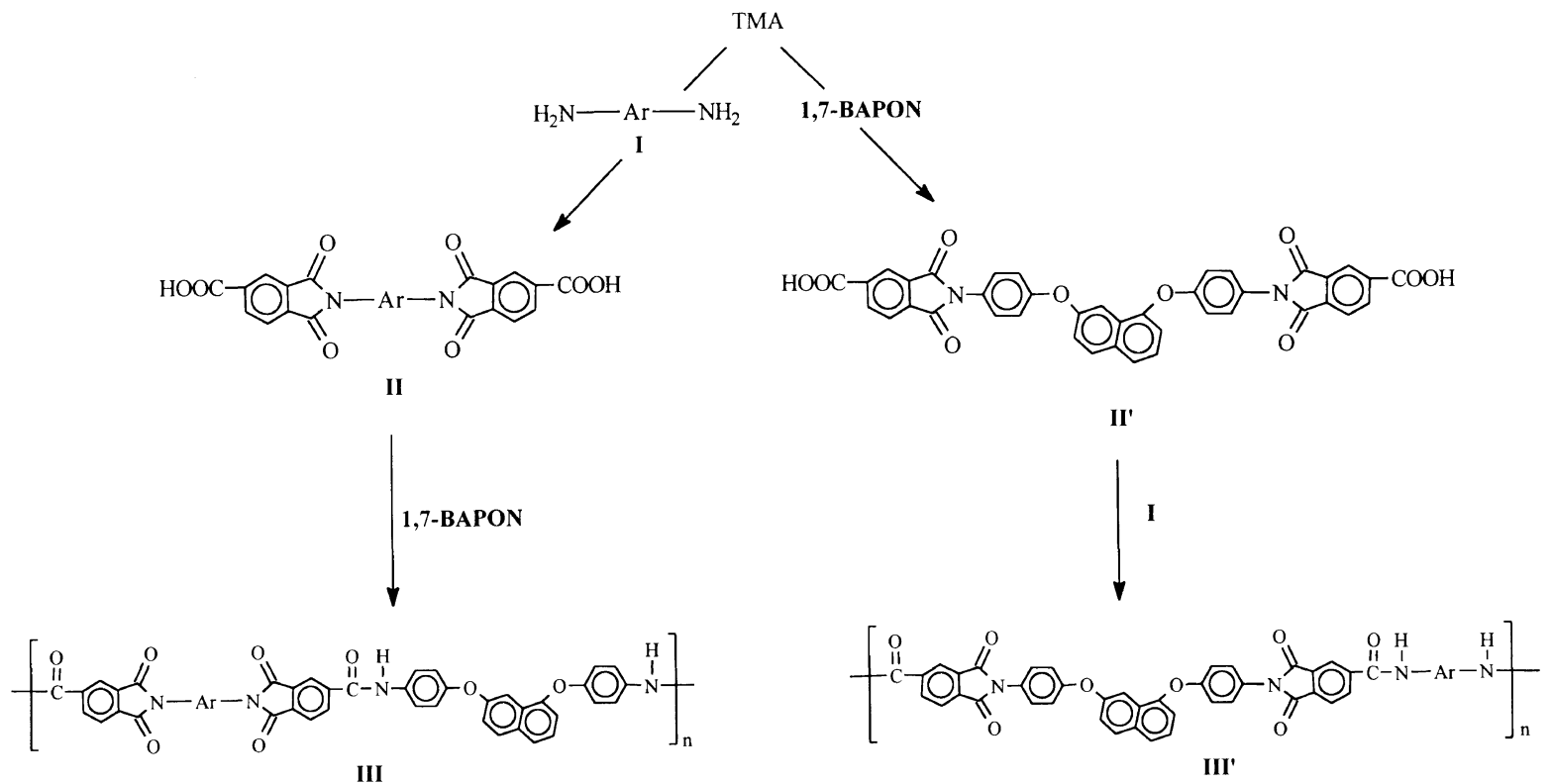

III

$\operatorname{Ar}$<smiles>Cc1ccc(I)cc1</smiles>

(c)<smiles>Cc1ccc(C)c(C)c1</smiles>

(d)<smiles>Cc1ccc(Cc2ccc(C)cc2)cc1</smiles>

(e) $-\mathrm{O}-\mathrm{O}$

(f)<smiles>Cc1ccc(Oc2cccc(I)c2)cc1</smiles>

(g)<smiles>Cc1ccc([SH](c2ccc(C)cc2)c2ccc(C)cc2)cc1</smiles>

(h)<smiles>Cc1ccc(Oc2ccc(Oc3ccc(C)cc3)cc2)cc1</smiles>

(i)

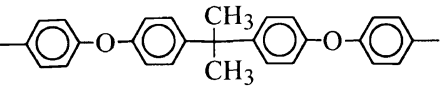

(j)<smiles>Cc1ccc(Oc2ccc(C(F)(F)C(F)(F)c3ccc(Oc4ccc(C)cc4)cc3)cc2)cc1</smiles>

(k)<smiles>Cc1ccc(Oc2ccc([Se]c3ccc(Oc4ccc(C)cc4)cc3)cc2)cc1</smiles>

(1)<smiles>Cc1ccc(Oc2ccc(C(C)(c3ccccc3)c3ccc(C)cc3)cc2)cc1</smiles>

Scheme 2. Preparation of poly(amide-imide)s.

the cases of IIIa and IIIh, early precipitation occurred during polymerization, and the polymers showed low inherent viscosity. Another possible reason for the low inherent viscosity of IIIa and IIIh is that the polymer chains (ether linkages) may decompose simultaneously during dissolution in concentrated sulfuric acid.

A typical IR spectrum is shown in Figure 1. The FT-IR spectrum of polymer III exhibited characteristic absorption bands for the imide ring at 1780 and 1719 (asymmetrical and symmetrical $\mathrm{C}=\mathrm{O}$ stretching vibration), 1380 (C-N stretching vibration), 1090 and 731 $\mathrm{cm}^{-1}$ (imide ring deformation). The absorptions of amide groups appeared at 3360,1680 , and $1600 \mathrm{~cm}^{-1}$. The IR spectrum of isomeric III'l is also shown. As seen from Figure 1, even though the spectra of these two isomeric polymers look very similar, the relative strength and positions of some absorptions also can be dis- tinguished in the spectra. The results of elemental analysis of Series III are listed in Table II. In all cases, the observed values of carbon and nitrogen were lower than those calculated for the proposed structures, but the hydrogen values were higher. This may result from the hygroscopic nature of amide groups of these polymers. The uptake of water was $1.72-4.40 \%$, calculated from the weight change of the polymer samples at $100^{\circ} \mathrm{C}$ under vacuum $10 \mathrm{~h}$ after exposure to air at room temperature for $8-10 \mathrm{~h}$. When corrected by eliminating absorbed water, the values were in good agreement those calculated.

\section{Properties of Polymer}

The qualitative solubility of PAIs in various solvents is listed in Table III. Most polymers were soluble in aprotic dipolar solvents such as DMAc, DMF, DMSO, 
Table I. Preparation of poly(amide-imide) $\mathrm{s}^{\mathrm{a}}$

\begin{tabular}{|c|c|c|c|c|c|c|}
\hline \multirow{2}{*}{ Polymer } & $\begin{array}{c}\text { Initial amount } \\
\text { of NMP }\end{array}$ & \multirow{2}{*}{$\begin{array}{c}\begin{array}{c}\text { Additional } \\
\text { amount of NMP }\end{array} \\
\mathrm{mL}\end{array}$} & \multirow{2}{*}{$\frac{\begin{array}{c}\text { Amount } \\
\text { of } \mathrm{CaCl}_{2}\end{array}}{\mathrm{~g}}$} & \multirow{2}{*}{$\frac{\text { Yield }}{\%}$} & \multirow{2}{*}{$\frac{\eta_{\mathrm{inh}}^{\mathrm{b}}}{\mathrm{dLg^{-1 }}}$} & \multirow{2}{*}{$\operatorname{Remark}^{\mathbf{d}}$} \\
\hline & $\mathrm{mL}$ & & & & & \\
\hline IIIa & 8 & 0 & 0.82 & 99 & $-^{c}$ & $\mathrm{P}$ \\
\hline IIIb & 6 & 0 & 0.60 & 99 & 0.50 & $\mathrm{~S}$ \\
\hline IIIc & 6 & 0 & 0.60 & 99 & 0.61 & $\mathrm{~S}$ \\
\hline IIIe & 6 & 4 & 0.56 & 99 & 0.91 & $\mathrm{~S}$ \\
\hline IIIf & 6 & 0 & 0.64 & 99 & 0.48 & $\mathrm{~S}$ \\
\hline IIIg & 6 & 5 & 0.60 & 99 & 0.74 & $S$ \\
\hline IIIh & 8 & 0 & 0.80 & 97 & $-^{c}$ & $\mathrm{P}$ \\
\hline IIIi & 6 & 8 & 0.60 & 99 & 0.77 & $\mathrm{~S}$ \\
\hline IIIj & 6 & 0 & 0.60 & 99 & 0.88 & $\mathrm{~S}$ \\
\hline IIIk & 6 & 0 & 0.56 & 99 & 0.57 & $\mathrm{~S}$ \\
\hline IIII & 6 & 3 & 0.60 & 99 & 0.68 & $\mathrm{~S}$ \\
\hline
\end{tabular}

${ }^{\text {a }}$ Polymerization was carried out with $1.25 \mathrm{mmol}$ of each monomer, $0.8 \mathrm{~mL}$ of triphenyl phosphite, $1.6 \mathrm{~mL}$ of pyridine, and calcium chloride in NMP at $100^{\circ} \mathrm{C}$ for $3 \mathrm{~h} .{ }^{\mathrm{b}}$ Measured at $30^{\circ} \mathrm{C}$ on a concentration of $0.5 \mathrm{~g} \mathrm{dL}^{-1}$ in DMAc, unless otherwise indicated. ${ }^{\mathrm{c}}$ Insoluble in DMAc and measured at $30^{\circ} \mathrm{C}$ on a concentration of $0.5 \mathrm{~g} \mathrm{dL}^{-1}$ in conc. $\mathrm{H}_{2} \mathrm{SO}_{4}\left(\eta_{\text {inh }}\right.$ of IIIa $=0.27$, $\eta_{\text {inh }}$ of IIIh $\left.=0.38\right)$, so polymer chains may be decomposed during the dissolution process. ${ }^{\mathrm{d}}$ Appearance of the polymerization mixture: $\mathrm{S}$, solution throughout the reaction; $\mathrm{P}$, precipitation during the reaction.

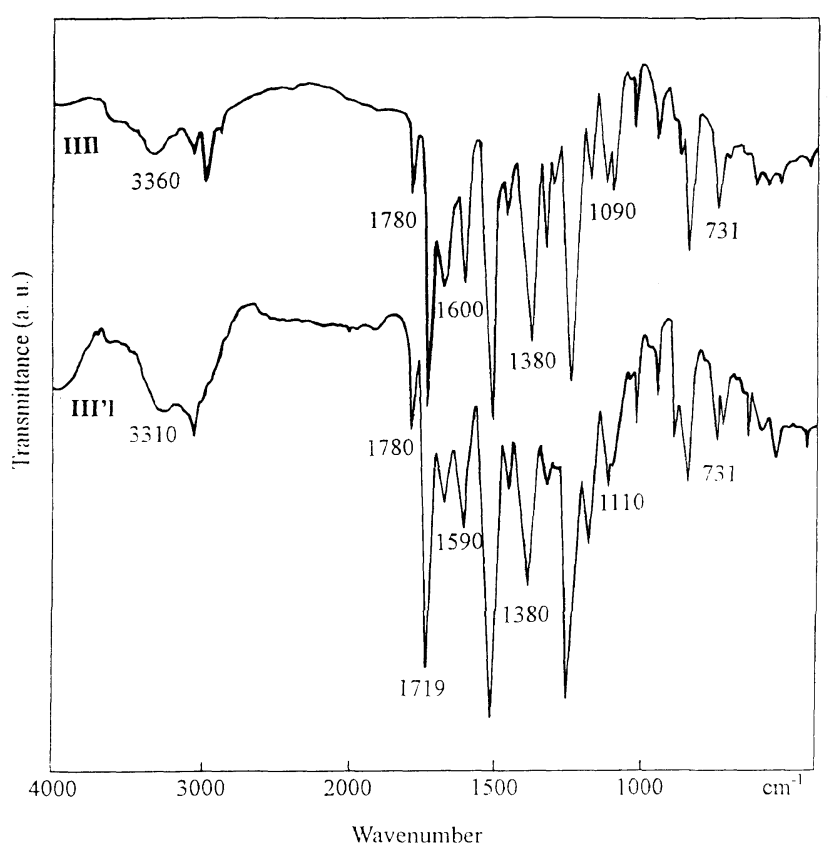

Figure 1. FT-IR spectra of poly(amide-imide)s IIII and III'I (film)

and NMP, and even in less polar $m$-cresol and pyridine. The polymers IIIa and IIIh were insoluble in all test solvents. The poor solubility of IIIa is related to the nature of rigid diimide-diacid IIa. Diimide-diacid was a p-phenoxy group-containing IIh, and early precipitation occurred during polymerization. The poor solubility of IIIh may be attributed to unsatisfactory results, possibly due to the presence of more para-oriented phenoxy linkages in polymer backbones that give a tighter packing tendency. The solvent molecules cannot penetrate into polymer packing to solubilize the chains, as noted for IIh-derived series PAIs. ${ }^{24}$ In a comparison of the solubilities of the polymers III with the corresponding polymers III', solubility behavior was virtually identical in most cases. The slight solubility differences between IIIe,g and III'e,g are believed to be related to the higher crystalline tendency of III'e and III'g, evident by X-ray diffraction patterns.

With the exception of organic-insoluble IIIa and IIIh, the tensile properties for most of the PAIs were obtained in the form of thin films cast from DMAc. The results are summarized in Table IV. These films had tensile strength of $73-103 \mathrm{MPa}$, elongation at break of $9-69 \%$, and initial modulus of $1.89-2.35 \mathrm{GPa}$, and some had yield strength. Polymers IIIi and IIIl showed distinct yield points on stress-strain curves and moderate elongation to break, indicative of high toughness. This may be due to the fact that the long chain diamine residues adopt a conformation that causes the polymer chain to coil strongly, through the disposition of the aromatic units adjacent to the ether linkages, but under stress these conformations are modified to give a more linear inchain unit. Effective uncoiling of the long chain diamine units about their ether linkages may be a mechanism for considerable chain extension.

To confirm the crystalline characteristics of these polymers, they were subjected to wide-angle X-ray diffraction measurement by powder (polymers IIIa and IIIh) or film (the other polymers) sampling using the nickel-filtered $\mathrm{Cu}-K_{\alpha}$ radiation. As shown in Figure 2, PAIs IIIa and IIIh showing slight crystalline nature relative to other polymers III had poor solubility in organic solvents, as mentioned above in Table III. The other polymers of Series III were amorphous. This is in agreement with the general rule that solubility decreases with increasing crystallinity. When compared the crystallinity differences between IIIe,g and III'e,g, III'e, and III'g exhibited one major peak at near $17^{\circ}$ and a minor one near $25^{\circ}$, indicative of a highly crystalline nature. However, IIIe and IIIg were amorphous, and this can be explained by the site of the large naphthalene group. Due to 1,7-BAPON located in amide-amide sequence, the packing of polymer chains in tight structures through hydrogen bonding between amide groups is probably disturbed and, consequently, IIIe,g showed amorphous patterns. 1,7-BAPON located in imide-imide sequence led to higher crystalline tendency.

The thermal behavior of the polymers was char- 
Poly(amide-imide)s Containing the 1,7-Bis(phenoxy)naphthalene Unit

Table II. Elemental analysis of poly(amide-imide)s

\begin{tabular}{|c|c|c|c|c|c|c|}
\hline \multirow{2}{*}{ Polymer } & \multicolumn{2}{|l|}{ Formula } & \multicolumn{3}{|c|}{ Elemental analysis $\mathbf{a} / \%$} & \multirow{2}{*}{$\begin{array}{c}\text { Moisture } \\
\text { uptakeb } / \%\end{array}$} \\
\hline & $M_{w}$ & & $\mathrm{C}$ & $\mathrm{H}$ & $\mathrm{N}$ & \\
\hline \multirow[t]{3}{*}{ IIIa } & $\left(\mathrm{C}_{46} \mathrm{H}_{26} \mathrm{~N}_{4} \mathrm{O}_{8}\right)_{n}$ & Calcd & 72.37 & 3.41 & 7.34 & \\
\hline & $(762.73)_{n}$ & Found & 70.04 & 3.50 & 7.07 & 3.12 \\
\hline & & Corrected & 72.23 & 3.39 & 7.29 & \\
\hline \multirow[t]{2}{*}{ IIIb } & $\left(\mathrm{C}_{46} \mathrm{H}_{26} \mathrm{~N}_{4} \mathrm{O}_{8}\right)_{n}$ & Calcd & 72.37 & 3.41 & 7.34 & \\
\hline & $(762.73)_{n}$ & Found & 69.24 & 3.53 & 7.00 & 4.33 \\
\hline \multirow[t]{3}{*}{ IIIc } & $\left(\mathrm{C}_{47} \mathrm{H}_{28} \mathrm{~N}_{4} \mathrm{O}_{8}\right)_{n}$ & Calcd & 72.61 & 3.60 & 7.21 & \\
\hline & $(776.76)_{n}$ & Found & 69.42 & 3.73 & 6.86 & 4.40 \\
\hline & & Corrected & 72.47 & 3.57 & 7.16 & \\
\hline \multirow[t]{3}{*}{ IIId } & $\left(\mathrm{C}_{52} \mathrm{H}_{30} \mathrm{~N}_{4} \mathrm{O}_{9}\right)_{n}$ & Calcd & 73.00 & 3.51 & 6.55 & \\
\hline & $(854.83)_{n}$ & Found & 70.49 & 3.60 & 6.30 & 3.44 \\
\hline & & Corrected & 72.91 & 3.48 & 6.52 & \\
\hline \multirow[t]{2}{*}{ IIIe } & $\left(\mathrm{C}_{52} \mathrm{H}_{30} \mathrm{~N}_{4} \mathrm{O}_{9}\right)_{n}$ & Calcd & 73.00 & 3.51 & 6.55 & \\
\hline & $(854.83)_{n}$ & Found & 70.53 & 3.59 & 6.31 & 3.38 \\
\hline \multirow{2}{*}{ IIIf } & $(852.86)_{n}$ & Found & 71.61 & 3.87 & 6.28 & 3.97 \\
\hline & & Corrected & 74.45 & 3.72 & 6.53 & \\
\hline \multirow[t]{3}{*}{ IIIg } & $\left(\mathrm{C}_{52} \mathrm{H}_{30} \mathrm{~N}_{4} \mathrm{O}_{8} \mathrm{~S}\right)_{n}$ & Calcd & 71.65 & 3.44 & 6.43 & \\
\hline & $(870.89)_{n}$ & Found & 69.22 & 3.53 & 6.17 & 3.39 \\
\hline & & Corrected & 71.57 & 3.41 & 6.38 & \\
\hline \multirow[t]{3}{*}{ IIIh } & $\left(\mathrm{C}_{58} \mathrm{H}_{34} \mathrm{~N}_{4} \mathrm{O}_{10}\right)_{n}$ & Calcd & 73.50 & 3.59 & 5.91 & \\
\hline & $(946.93)_{n}$ & Found & 72.24 & 3.62 & 5.79 & 1.72 \\
\hline & & Corrected & 73.48 & 3.56 & 5.89 & \\
\hline \multirow[t]{3}{*}{ IIIi } & $\left(\mathrm{C}_{67} \mathrm{H}_{44} \mathrm{~N}_{4} \mathrm{O}_{10}\right)_{n}$ & Calcd & 75.49 & 4.13 & 5.26 & \\
\hline & $(1065.11)_{n}$ & Found & 73.14 & 4.23 & 5.07 & 3.11 \\
\hline & & Corrected & 75.41 & 4.10 & 5.23 & \\
\hline \multirow[t]{3}{*}{ IIIj } & $\left(\mathrm{C}_{67} \mathrm{H}_{38} \mathrm{~N}_{4} \mathrm{O}_{10} \mathrm{~F}_{6}\right)_{n}$ & Calcd & 68.54 & 3.24 & 4.77 & \\
\hline & $(1173.05)_{n}$ & Found & 67.16 & 3.27 & 4.64 & 2.01 \\
\hline & & Corrected & 68.51 & 3.20 & 4.73 & \\
\hline \multirow[t]{3}{*}{ IIIk } & $\left(\mathrm{C}_{64} \mathrm{H}_{38} \mathrm{~N}_{4} \mathrm{O}_{12} \mathrm{~S}\right)_{n}$ & Calcd & 70.65 & 3.50 & 5.15 & \\
\hline & $(1087.09)_{n}$ & Found & 68.78 & 3.56 & 4.98 & 2.65 \\
\hline & & Corrected & 70.60 & 3.47 & 5.11 & \\
\hline IIII & & Corrected & 76.58 & 4.05 & 4.92 & \\
\hline
\end{tabular}

${ }^{a}$ For $\mathrm{C}$ and $\mathrm{N}$ : Corrected value $=$ found value $\times(100 \%+$ moisture uptake $\%)$. For $\mathrm{H}$ : Corrected value $=$ found value $\times(100 \%-\mathrm{moisture}$ uptake \%). ${ }^{\mathrm{b}}$ Moisture uptake $(\%)=\left(W-W_{0} / W_{0}\right) \times 100 \% ; W=$ weight of polymer sample after standing at room temperature, and $W_{0}=$ weight of polymer sample after dried in vacuum at $100^{\circ} \mathrm{C}$ for $10 \mathrm{~h}$.

Table III. Solubility of poly(amide-imide) $\mathrm{s}^{\mathrm{a}}$

\begin{tabular}{|c|c|c|c|c|c|c|c|}
\hline \multirow{2}{*}{ Polymer } & \multicolumn{7}{|c|}{ Solvent ${ }^{b}$} \\
\hline & DMAc & NMP & DMF & DMSO & $m$-Cresol & $o$-Chloro & Py \\
\hline IIIa & - & - & - & - & - & - & - \\
\hline IIIb & + & + & - & - & + & + & + \\
\hline IIIc & + & + & + & \pm & + & + & + \\
\hline$\left(\mathbf{I I I}^{\prime} \mathbf{c}\right)$ & $(+)$ & $(+)$ & $(+)$ & $(\overline{+})$ & $(+)$ & $(+)$ & $(+)$ \\
\hline IIId & + & + & + & + & + & + & - \\
\hline IIIe & + & + & - & \pm & - & - & - \\
\hline (III'e) & $(-)$ & $(-)$ & $(-)$ & $(-)$ & $(-)$ & $(-)$ & $(-)$ \\
\hline $\begin{array}{l}\text { IIIf } \\
(\mathbf{I I I} \mathbf{f})\end{array}$ & $\begin{array}{l}+ \\
(+)\end{array}$ & $\begin{array}{c}+ \\
(+)\end{array}$ & $\begin{array}{l}+ \\
(-)\end{array}$ & $\begin{array}{l}+ \\
(+)\end{array}$ & $\begin{array}{l}+ \\
(-)\end{array}$ & $\begin{array}{l}+ \\
(-)\end{array}$ & $\begin{array}{l}+ \\
(-)\end{array}$ \\
\hline IIIg & + & + & + & - & - & - & - \\
\hline$\left(\mathbf{I I I}^{\prime} \mathbf{g}\right)$ & $(-)$ & $(-)$ & $(-)$ & $(-)$ & $(-)$ & $(-)$ & $(-)$ \\
\hline IIIh & - & - & - & - & - & - & - \\
\hline IIIi & + & + & - & - & - & - & \pm \\
\hline$\left(\mathbf{I I I}^{\prime} \mathbf{i}\right)$ & $(+)$ & $(+)$ & $(+)$ & $(-)$ & $( \pm)$ & $(+)$ & $(+)$ \\
\hline $\mathrm{IIIj}$ & + & + & + & + & + & + & \pm \\
\hline$(\mathbf{I I I} \mathbf{j} \mathbf{j})$ & $(+)$ & $(+)$ & $(+)$ & $(-)$ & $(+)$ & $(+)$ & $(+)$ \\
\hline IIIk & + & + & - & + & + & + & - \\
\hline (III'k) & $(+)$ & $(+)$ & $( \pm)$ & $(+)$ & $(-)$ & $(-)$ & $(-)$ \\
\hline $\begin{array}{l}\text { IIII } \\
(\text { III'l'I) }\end{array}$ & $\begin{array}{c}+ \\
(+)\end{array}$ & $\begin{array}{c}+ \\
(+)\end{array}$ & $\overline{(+)}$ & $\begin{array}{c}+ \\
( \pm)\end{array}$ & $\frac{-}{(+)}$ & $\begin{array}{c}+ \\
(+)\end{array}$ & $\stackrel{ \pm}{(+)}$ \\
\hline
\end{tabular}

${ }^{a}+$, soluble; - , insoluble; \pm , partially soluble. Solubility behavior indicated in parentheses is that of polymers III' reported in ref $14 .{ }^{b}$ DMAc, $N, N^{\prime}$-dimethylacetamide; DMF, $N, N$-dimethylformamide; NMP, $N$-methyl-2-pyrrolidone; DMSO, dimethylsulfoxide; Py, pyridine; o-Chloro, $o$-chlorophenol. 
Table IV. Tensile properties of poly(amide-imide) films

\begin{tabular}{|c|c|c|c|c|}
\hline \multirow{2}{*}{ Polymer } & $\begin{array}{l}\text { Strength } \\
\text { at yield }\end{array}$ & $\begin{array}{l}\text { Strength } \\
\text { at break }\end{array}$ & $\begin{array}{c}\text { Elongation } \\
\text { to break }\end{array}$ & $\begin{array}{l}\text { Initial } \\
\text { modulus }\end{array}$ \\
\hline & $\mathrm{MPa}$ & $\mathrm{MPa}$ & $\%$ & $\mathrm{GPa}$ \\
\hline IIIb & - & 85 & 9 & 2.00 \\
\hline IIIc & - & 103 & 11 & 2.35 \\
\hline IIId & 95 & 73 & 28 & 2.01 \\
\hline IIIe & 96 & 79 & 16 & 1.94 \\
\hline IIIf & - & 95 & 12 & 1.93 \\
\hline IIIg & - & 84 & 12 & 1.92 \\
\hline IIli & 89 & 77 & 69 & 1.89 \\
\hline IIIj & 97 & 81 & 11 & 2.21 \\
\hline IIIK & 85 & 81 & 23 & 1.91 \\
\hline IIII & 97 & 78 & 57 & 2.11 \\
\hline
\end{tabular}

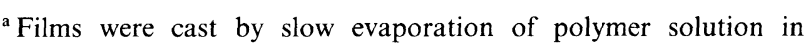
DMAc.

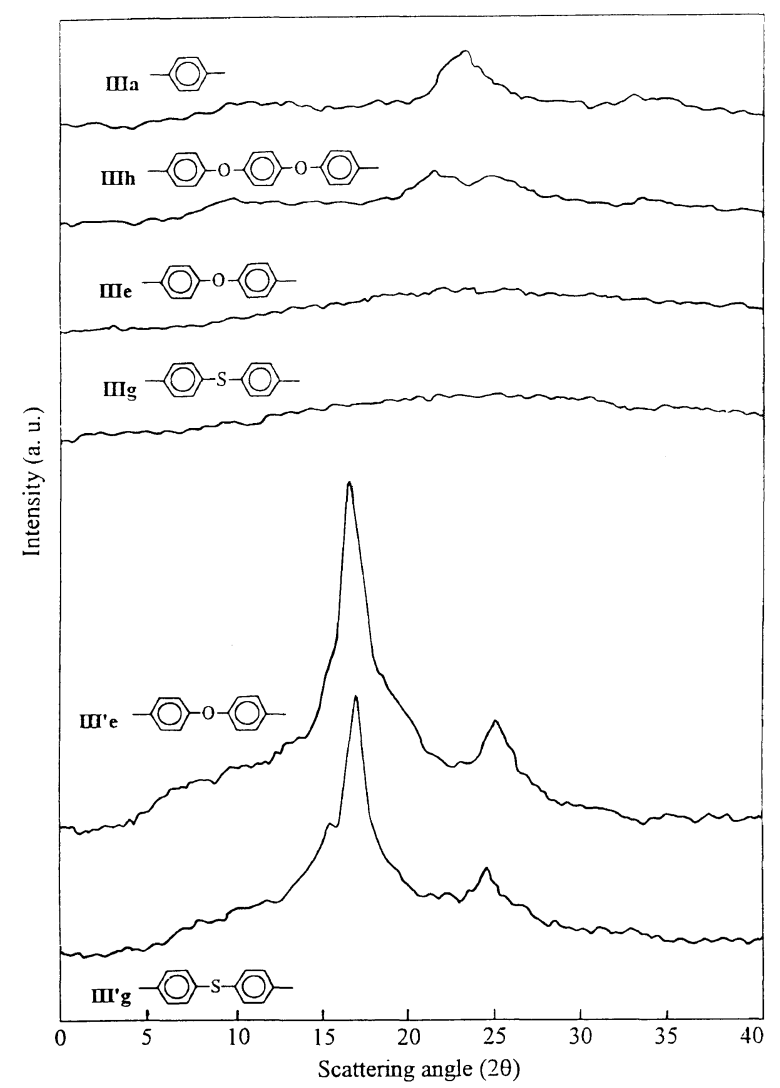

Figure 2. Wide-angle X-ray diffractograms of some poly(amideimide)s.

acterized using DSC and thermogravimetric analysis (TGA). Table $\mathrm{V}$ summarizes the thermal transition data of PAIs. DSC measurements were conducted at a heating rate of $20^{\circ} \mathrm{C} \mathrm{min}^{-1}$. Quenching from the elevated temperatures $\left(400^{\circ} \mathrm{C}\right)$ to room temperature in air yields more amorphous samples so that in most cases the glass transition temperatures $\left(T_{\mathrm{g}} \mathrm{s}\right)$ could be easily measured in the second heating. No discernible $T_{\mathrm{g}} \mathrm{s}$ of the polymers IIIa, IIIb, and IIIf were detected from DSC. The $T_{\mathrm{g}} \mathrm{s}$ of most polymers III were in the range of $213-250^{\circ} \mathrm{C}$. A melting endotherm peak of polymer IIIh could be observed on the first heating run. High $T_{\mathrm{g}} \mathrm{s}$ and no discernible melting endotherm of most of polymers III were detected from DSC. This may be due to the effects
Table V. Thermal data of poly(amide-imide)s

\begin{tabular}{|c|c|c|c|c|c|}
\hline \multirow{4}{*}{ Polymer } & \multirow{2}{*}{\multicolumn{2}{|c|}{ DSC }} & \multicolumn{3}{|c|}{ TGA } \\
\hline & & & \multirow{2}{*}{\multicolumn{2}{|c|}{$\begin{array}{l}\text { Decomposition } \\
\text { temperature }{ }^{\mathrm{c}} /{ }^{\circ} \mathrm{C}\end{array}$}} & \multirow{3}{*}{$\begin{array}{c}\text { wt } \% \\
\text { Residual } \\
\text { at } 800^{\circ} \mathrm{C} \\
\text { in } \mathrm{N}_{2}\end{array}$} \\
\hline & $T_{\mathrm{g}}^{\mathrm{a}} /{ }^{\circ} \mathrm{C}$ & $T_{\mathrm{m}}^{\mathrm{b}} /{ }^{\circ} \mathrm{C}$ & & & \\
\hline & & & In air & In nitrogen & \\
\hline IIIa & ${ }^{\mathrm{d}}$ & - & 492 & 518 & 67 \\
\hline IIIb & - & - & 513 & 550 & 58 \\
\hline IIIc & $250(258)^{\mathrm{c}}$ & $-(-)$ & $514(521)$ & $534(530)$ & $62(63)$ \\
\hline IIId & 243 & - & 531 & 550 & 62 \\
\hline IIIe & $236(-)$ & $-(-)$ & $534(500)$ & $536(552)$ & $57(59)$ \\
\hline IIIf & $-(267)$ & $-(-)$ & $488(527)$ & $549(558)$ & $69(60)$ \\
\hline IIIg & $237(-)$ & $-(-)$ & $540(491)$ & $532(551)$ & $63(58)$ \\
\hline IIIh & 250 & 375 & 532 & 544 & 61 \\
\hline IIIi & $213(243)$ & $-(-)$ & $535(492)$ & $514(523)$ & $50(52)$ \\
\hline IIIj & $240(249)$ & $-(-)$ & $519(509)$ & $553(557)$ & $62(59)$ \\
\hline IIIk & $228(263)$ & $-(-)$ & $505(525)$ & $522(537)$ & $51(57)$ \\
\hline IIII & $245(222)$ & $-(-)$ & $532(529)$ & $579(518)$ & $79(51)$ \\
\hline
\end{tabular}

${ }^{a}$ From second heating traces of DSC measurements conducted with a heating rate of $20^{\circ} \mathrm{C} \mathrm{min}-1$ in nitrogen. ${ }^{b}$ Temperature of the endotherm peak in the first heating trace of DSC. ${ }^{\mathrm{c}}$ Temperature at which a $10 \%$ weight loss was recorded by TG at a heating rate of $20^{\circ} \mathrm{Cmin}^{-1}$. ${ }^{\mathrm{d}}$ No $T_{\mathrm{g}}$ or $T_{\mathrm{m}}$ was observed in DSC trace. ${ }^{\mathrm{e}}$ Data in the parentheses are those of the corresponding isomeric poly(amideimide)s of the III' series.

of rigid naphthalene linkages in polymer chains. On comparing $T_{\mathrm{g}}$ of polymers III with their analogous III', their $T_{\mathrm{g}} \mathrm{s}$ do not show any clear dependence on the site of the 1,7-BAPON moiety.

The thermal properties of all PAIs are summarized in Table V. $10 \%$ weight loss temperatures $\left(T_{10} \mathrm{~s}\right)$ of Series III were in the range of $514-579^{\circ} \mathrm{C}$ in nitrogen and $488-540^{\circ} \mathrm{C}$ in air. The thermogravimetric traces indicate that polymers III possess moderately high thermal stability with no significant weight loss up to approximately $450^{\circ} \mathrm{C}$ in a nitrogen or an air atmosphere. By comparing Series III and Series III', the thermal stability of Series III and isomers Series III' did not display significant difference.

\section{CONCLUSIONS}

1,7-Bis(phenoxy)naphthalene-containing PAIs with moderate to high molecular weights could be easily obtained by direct polycondensation reaction of 1,7-bis(4-aminophenoxy)naphthalene (1,7-BAPON) and aromatic bis(trimellitimide)s by triphenyl phosphite in NMP-pyridine solution in the presence of calcium chloride. The resulting PAIs generally showed high thermal stability and good solubility, and the cast films exhibited excellent tensile properties. The 1,7-BAPON located in amide-amide sequence led to a lower crystalline tendency than in imide-imide sequence, however, polymer still maintained thermal stability. Thus, these PAIs are considered promising high-temperature polymer materials.

\section{REFERENCES}

1. Y. Imai, N. N. Maldar, and M. Kakimoto, J. Polym. Sci., Part A, Polym. Chem., 23, 2077 (1985).

2. W. Wrasidlo and J. M. Augl, J. Polym. Sci., Part A, Polym. Chem., 7, 321 (1969). 
3. J. L. Nieto, J. G. de la Campa, and J. de Abjo, Makromol. Chem., 183, 557 (1982).

4. N. Yamazaki and F. Higashi, Tetrahedron Lett., 28, 5074 (1972).

5. N. Yamazaki and F. Higashi, Tetrahedron Lett., 30, 1323 (1974).

6. N. Yamazaki, M. Matsumoto, and F. Higashi, J. Polym. Sci., Part A, Polym. Chem., 13, 1373 (1975).

7. W. F. Hale, A. G. Farnham, R. N. Johnson, and R. A. Clendining, J. Polym. Sci., Part A, Polym. Chem., 5, 2399 (1967).

8. B. F. Malichenko, V. V. Sherikova, L. C. Chorvgatsova, A. A. Kachan, and G. I. Motryuk, Vysokomol Soedin. Ser. B, 14, 423 (1972).

9. C. P. Yang and W. T. Chen, Makromol. Chem., 193, 2323 (1992).

10. C. P. Yang and W. T. Chen, Makromol. Chem., 194, 1595 (1993).

11. C. P. Yang and W. T. Chen, Makromol. Chem., 194, 3061 (1993).

12. C. P. Yang and W. T. Chen, J. Polym. Sci., Part A, Polym. Chem., 31, 1571 (1993).

13. C. P. Yang and W. T. Chen, J. Polym. Sci., Part A, Polym. Chem., 31, 2799 (1993).
14. C. P. Yang and W. T. Chen, Macromolecules, 26, 4865 (1993).

15. C. P. Yang and J. H. Lin, J. Polym. Res., 3, 193 (1996).

16. C. P. Yang and W. T. Chen, Makromol. Chem., 194, 3071 (1993).

17. C. P. Yang and W. T. Chen, J. Polym. Sci., Part A, Polym. Chem., 31, 3081 (1993).

18. C. P. Yang and W. T. Chen, J. Polym. Sci., Part A, Polym. Chem., 32, 435 (1994).

19. C. P. Yang and W. T. Chen, J. Polym. Sci., Part A, Polym. Chem., 32, 1101 (1994).

20. C. P. Yang, S. H. Hsiao, and C. C. Yang, J. Polym. Sci., Part A, Polym. Chem., 36, 919 (1998).

21. K. Suematsu, Macromolecules, 18, 2085 (1985).

22. C. P. Yang and J. H. Lin, J. Polym. Sci., Part A, Polym. Chem., 33, 2183 (1995).

23. R. S. Chen and C. P. Yang, J. Polym. Res., 5, 233 (1998).

24. C. P. Yang, S. H. Hsiao, and W. L. Chou, J. Polym. Res., 2, 179 (1995). 